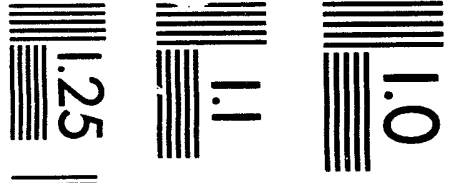

$$
\begin{aligned}
& \sqrt{\sqrt{\overline{2}}}
\end{aligned}
$$

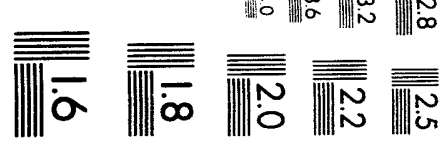



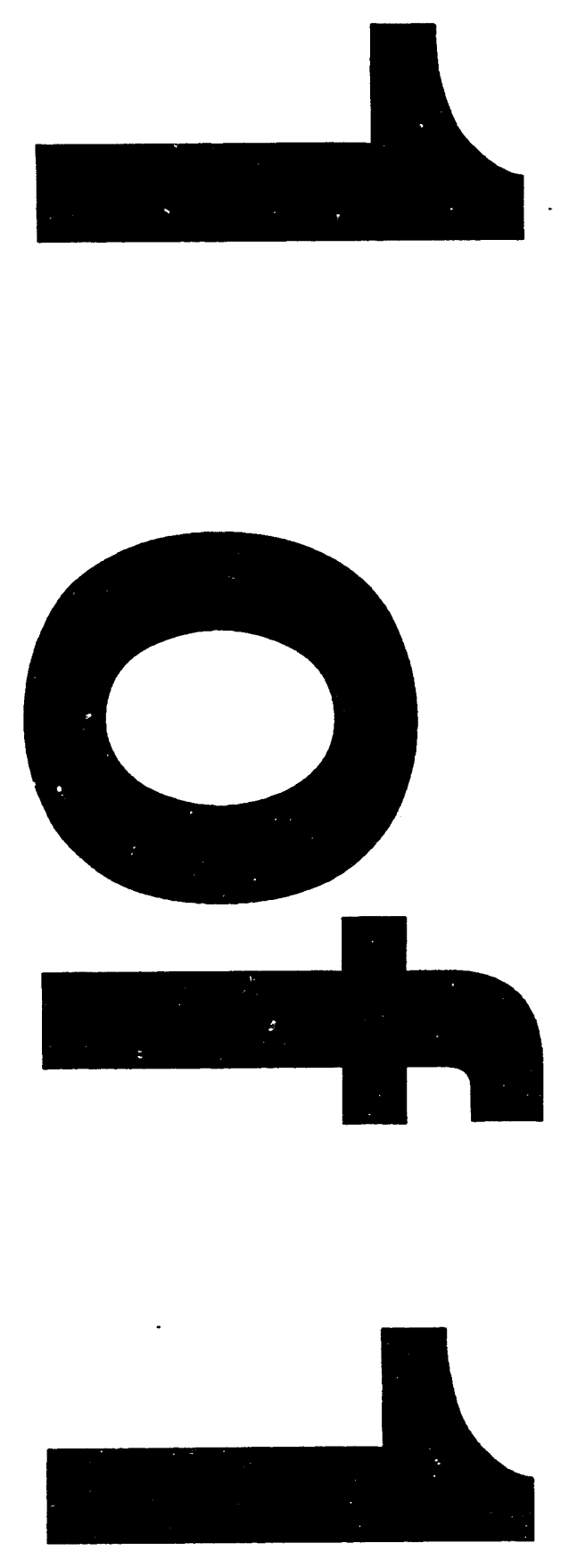


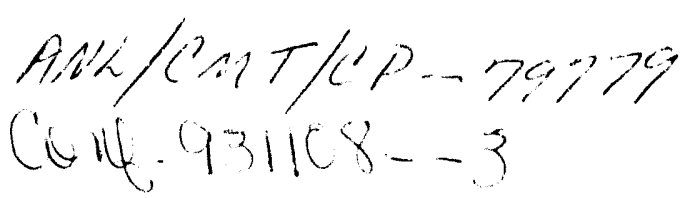

\title{
ELEMENTS PRESENT IN LEACH SOLUTIONS FROM UNSATURATED SPENT FUEL TESTS
}

\author{
P. A. Finn, J. K. Bates, J. C. Hoh, J. W. Emery, \\ L. D. Hafenrichter, E. C. Buck, and M. Gong
}

\author{
ARGONNE NATIONAL LABORATORY \\ Chemical Technology Division \\ 9700 South Cass Avenue \\ Argonne, IL 60439 \\ DISCLAIMER
}

\begin{abstract}
This report was prepared as an account of work sponsored by an agency of the United States Government. Neither the United States Government nor any agency thereof, nor any of their employees, makes any warranty, express or implied, or assumes any legal liability or responsibility for the accuracy, completeness, or usefulness of any information, apparatus, product, or process disclosed, or represents that its use would not infringe privately owned rights. Referace herein to any specific commercial product, process, or servici by trade name, trademark, manufacturer, or otherwise does not necessarily constitute or imply its endorsement, recommendation, or favoring by the United States Government or any agency thereof. The views and opinions of authors expressed herein do not necessarily state or reflect those of the United States Government or any agency thereof.
\end{abstract}

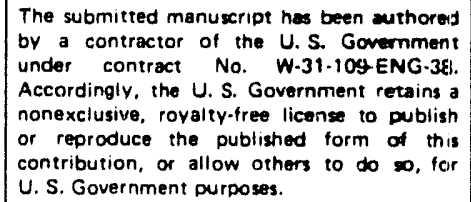

Submitted to

Fall 1993 Materials Research Society Meeting

Boston, MA

November 29-December 3, 1993

Work supported by the U.S. Department of Energy: under Contract W-31-109-ENG-38. 


\section{ELEMENTS PRESENT IN LEACH SOLUTIONS FROM UNSATURATED SPENT FUEL TESTS}

P. A. Finn, J. K. Bates, J. C. Hoh, J. W. Emery, L. D. Hafenrichter, E. C. Buck, and M. Gong, Argonne National Laboratory, Chemical Technology Division, 9700 S. Cass Avenue, Argonne, IL 60439.

\section{ABSTRACT}

Preliminary results for the composition of the leachate from unsaturated tests at $90^{\circ} \mathrm{C}$ with spent fuel for $55-134$ days with $\mathrm{J}-13$ groundwater are reported. The $\mathrm{pH}$ of the leachate solutions was found to be acidic, ranging from 4 to 7 . The actinide concentrations were $10^{5}$ greater than those reported for saturated spent fuel tests in which the leachate $\mathrm{pH}$ was 8 . We also found that most species in the leachate were present as colloids containing both americium and curium. The presence of actinides in a form not currently included in repository radionuclide transport models provides information that can be used in spent fuel reaction modeling, the performance assessment of the repository and the design of the engineering barrier system.

\section{INTRODUCTION}

The potential repository to be located in the volcanic tuff beds at Yucca Mountain, Nevada is being evaluated for the permanent disposal of spent nuclear fuel. After a period of time (1000 years) depending on emplacement scenarios the cladding could fail and the spent fuel would be exposed to water condensation. In earlier studies, dissolution of spent fuel in a saturated water environment was measured with intermittent exchange water immersion tests at 25 and $85^{\circ} \mathrm{C}$ [1] and dynamic flow-through tests at $25^{\circ} \mathrm{C}[2,3]$. In both conditions, a slow dissolution of the spent fuel matrix was observed, and the actinide solubility limit depended on matrix dissolution. However, the evaluation of the performance of spent fuel in a realistic repository environment would include that under anticipated unsaturated conditions [4]. We therefore initiated tests in which spent fuel is exposed to small amounts of liquid water, $0.075 \mathrm{~mL} / 3.5 \mathrm{~d}$, which is equivalent to a water infiltration rate of $0.5 \mathrm{~mm} / \mathrm{yr}$, that expected at Yucca Mountain [5]. Tests were also conducted at the higher rate of $0.75 \mathrm{~mL} / 3.5 \mathrm{~d}$.

Our unsaturated leach tests are designed to simulate and monitor the release of radionuclides from the spent fuel after cladding failure. They yield information on the (1) chemistry of the solutions after contact with the spent fuel as a function of time, (2) the dissolution rate of the spent fuel matrix, (3) the species form and type (ion, colloid) of the released radionuclides, and (4) the release rate of the radionuclides. The results can then be used to identify processes that affect spent fuel performance and radionuclide release rates under unsaturated conditions, provide data to validate models that predict the long-term behavior of spent fuel within the repository, and provide information regarding the distribution of radionuclides in solution.

\section{EXPERIMENTAL}

\section{Materials}

Two types of spent fuel from a pressurized water reactor (PWR) were tested: ATM-103 and ATM-106. Burnup and fission gas release (FGR) characteristics of these two types are given in Table I. Radionuclide inventories of the fuels were 
taken from ORIGEN2 calculations given in Refs. 6 and 7. The fuel was received in the form of fragments and was placed on a 20-mesh sieve to remove fines. The percent fuel larger than 20-mesh being $99.9 \%$ for ATM-103 and $98.9 \%$ for ATM-106. The average geometric surface area of the fragments was $2.1 \mathrm{~cm} 2 / \mathrm{g}$.

The groundwater used originates from well J-13, located near Yucca Mountain, $N:$, and has a chemistry representative of the saturated zone. The water was equilibrated with Topopah Spring tuff at $90^{\circ} \mathrm{C}$, a fluid more representative of recharged water, and is designated EJ-13 (see Table III).

\section{Test Matrix}

The test matrix shown in Table II. The spent fuel was placed inside a Zircaloy-4 cladding tube. The tube was placed on a Zircaloy-4 support stand inside the test vessel. The base of the Zircaloy-4 support stand contained a $20-\mu \mathrm{m}$-thick Zircaloy-4 filter to separate the spent fuel from the leach solution. This assembly was set on a ledge inside a $304 \mathrm{~L}$ stainless steel test vessel, with $5-10 \mathrm{~mL}$ EJ-13 water below the assembly. The vessel was sealed with a copper gasket at $100 \mathrm{ft}-\mathrm{lb}$ $(135 \mathrm{~J})$ torque. Each test vessel was placed in an electric oven held at a constant temperature of $90^{\circ} \mathrm{C}$. All tests use this experimental configuration.

The water injection system consists of an automated six-way valve and associated piping to introduce $\mathrm{EJ}-13$ water from a common reservoir into the appropriate test vessel in graduated amounts at the defined interval. Before the start of the tests, the vessels and the injection system underwent conditioning with deionized water and EJ-13 water, respectively.

A control test (CC) at the lower injection rate was conducted to determine the effect of gamma radiolysis on the water environment within the test vessel, the extent of contamination within the hot cell, and the effect of the test vessel on the solution chemistry.

\section{Leachate Analysis}

Aliquots of the solutions in the base of the test vessels were taken in intervals of $\sim 60$ days, after 55-83 and 113-134 days, to determine the rate and extent of radionuclide leaching. These aliquots were examıned for $\mathrm{pH}$, carbon and anion content, and alpha radionuclide speciation between dissolved and suspended material. Also suspended material was characterized by transmission electron microscopy (TEM). Alpha spectroscopy was done on unfiltered and filtered (3.6-nm filter) aliquots. Inductively coupled plasma-mass spectrometry (ICP-MS) analysis is in progress for cation identification. At each sampling period, the fuel surface was examined using an in-cell microscope and video system, with observations being taped for future analysis. The tests will continue until steadystate solution concentrations are reached.

TABLE I. Characteristics of PWR Spent Fuel

\begin{tabular}{lcccccc}
\hline Fuel & Rod & $\begin{array}{c}\text { Burnup } \\
(\mathrm{MW} \cdot \mathrm{d} / \mathrm{kg} M)\end{array}$ & $\begin{array}{c}\text { FGR } \\
(\%)\end{array}$ & $\begin{array}{c}\text { Decay } \\
\text { Time }(\mathrm{yr})\end{array}$ & $\begin{array}{c}\text { Dose Rate } \\
(\mathrm{Ci} / \mathrm{g} \text { U) }\end{array}$ & Reference \\
\hline ATM-103 & MLA-098 & 30 & 0.25 & 13 & 0.31 & {$[6]$} \\
ATM-106 & NBD-107 & 42 & 11 & 13 & 0.43 & {$[7]$} \\
\hline
\end{tabular}


TABLE II. Conditions for Unsaturated Tests of Spent Fuel at $90^{\circ} \mathrm{C}$

\begin{tabular}{lccccc}
\hline Testa & Fuel & Wt. (g) & Water Form & mL/3.5 d & $\begin{array}{c}\text { Vessel } \\
\text { (mL) }\end{array}$ \\
\hline S31J1 & ATM-103 & 8.81 & Vapor/Liquid & 0.075 & 5 \\
S61J1 & ATM-106 & 7.22 & Vapor/Liquid & 0.075 & 5 \\
S32J1 & ATM-103 & 8.62 & Vapor/Liquid & 0.75 & 5 \\
S62J1 & ATM-106 & 8.01 & Vapor/Liquid & 0.75 & 5 \\
S3V1 & ATM-103 & 8.78 & Vapor & - & 10 \\
S6V1 & ATM-106 & 8.02 & Vapor & - & 10 \\
CC1J1 & None & -- & Vapor/Liquid & 0.075 & 5 \\
\hline
\end{tabular}

aThe total test time was 55-134 days. The gamma dose rate for the liquid in the control vessel is $5 \mathrm{R} / \mathrm{h}$ at its outer surface. The gamma dose rate for the liquid in the other vessels is significantly higher.

\section{RESULTS AND DISCUSSION}

\section{Solution Analyses}

Leachates from the unsaturated tests have been analyzed at 55-83 and 113-134 days of testing. The $\mathrm{pH}$ for the injection tests is that calculated for the undiluted leachate. The $\mathrm{pH}$ of all seven tests is lower than that of EJ-13 $(\mathrm{pH}=8.36)$. The control test has a constant $\mathrm{pH}$ of 6.5. The $\mathrm{pH}$ 's for both vapor tests (S3V1 and S6V1) are relatively constant at 7.4 and 7.1, which are higher than the $\mathrm{pH}$ in the control test. The two injection tests with ATM-103 fuel (S31J1 and S32J1) have approximately the same $\mathrm{pH}$ after four months, 6.5 and 6.3. These latter values are close to the control test $\mathrm{pH}$. After four months, the injection tests with ATM-106 fuel (S61J1 and S62J1), which has a dose rate $150 \%$ higher than that of ATM-103, do not appear to have stabilized, although the pH of S62J1 has decreased to 4.7 at $113 \mathrm{~d}$. For test S32J1, the pH was 6.0 at $57 \mathrm{~d}$ and 6.3 at $120 \mathrm{~d}$. The acidic pHs in these tests are the result of radiolysis and, as will be discussed later, produce higher actinide solubilities [8] than those reported for saturated solutions [1] of $10^{-8} \mathrm{~g} / \mathrm{L}$.

As shown in Table III, only the fluid in the control test maintains an inorganic carbon content comparable to the initial EJ-13. The inorganic carbon contents of tests S32J1 and S62J1 are drastically lower than the initial EJ-13, but their organic carbon content is comparable to the initial EJ-13. The organic carbon content and the sum of the formate and oxalate contents are comparable. For S32J1 after 57 days, the organic carbon content is $6.3 \times 10^{-3} \mathrm{~g} / \mathrm{L}$, whereas the formate/oxalate content is $9.2 \times 10^{-3} \mathrm{~g} / \mathrm{L}$; for $\mathrm{S} 32 \mathrm{~J} 1$ at 120 days, the respective values are 4.2 and $10.6 \times 10^{-3}$.

Other effects of radiolysis on solution composition were determined by comparing the change in the formate, bicarbonate, nitrite, and nitrate content versus that in the original EJ-13. The mole change of these four anions for both intervals is shown in Table IV. The nitrate content does not exhibit a large change, although it consistently decreased. However, the nitrite increase is an order of magnitude greater than the nitrate decrease. This finding indicates that nitrogen is being oxidized due to air radiolysis. However, this hypothesis could not be confirmed because the gas composition within the test vessels was not measured. 
TABLE III. Composition of Spent Fuel Leachatea and EJ-13.

Units are $10^{-3} \mathrm{~g} / \mathrm{L}$ unless stated otherwise.

\begin{tabular}{|c|c|c|c|c|c|c|c|c|}
\hline Test & $532 \mathrm{J1}$ & S62J1 & $\mathrm{CC}_{1 \mathrm{~J} 1}$ & S31J1 & S61J1 & S3V1 & $\mathrm{S} \mathrm{V}_{1} \mathrm{~b}$ & EJ-13 \\
\hline $\begin{array}{l}\text { Total Time (d) } \\
\text { pH }\left(25^{\circ} \mathrm{C}\right) \\
\text { Tot. Carbon } \\
\text { Org. Carbon } \\
\text { Inorg. Carbon } \\
\text { Formate } \\
\text { Oxalate } \\
\text { Nitrite } \\
\text { Nitrate }\end{array}$ & $\begin{array}{c}57 \\
5.95 \\
8.1 \\
6.3 \\
1.8 \\
6 . \\
3.2 \\
21 \\
7.3 \\
\end{array}$ & $\begin{array}{c}55 \\
6.20 \\
10.9 \\
8.3 \\
2.6 \\
6.3 \\
2.1 \\
19 \\
5.0 \\
\end{array}$ & $\begin{array}{c}57 \\
6.51 \\
29.5 \\
11.6 \\
17.9 \\
5.7 \\
<2 \\
1.4 \\
6.7 \\
\end{array}$ & $\begin{array}{c}71 \\
5.44 \\
29.6 \\
25.1 \\
4.5 \\
14 \\
<2 \\
36 \\
7.7 \\
\end{array}$ & $\begin{array}{c}74 \\
5.59 \\
37.9 \\
33.1 \\
4.8 \\
17 \\
<2 \\
33 \\
6.7 \\
\end{array}$ & $\begin{array}{c}82 \\
7.32 \\
37.3 \\
27.6 \\
9.7 \\
16 \\
<2 \\
26 \\
6.6 \\
\end{array}$ & $\begin{array}{l}83 \\
7.11 \\
41.7 \\
31.4 \\
10.3 \\
16 \\
3.9 \\
31 \\
7.6 \\
\end{array}$ & $\begin{array}{l}\overline{8} .36 \\
25.0 \\
5.0 \\
20.0 \\
<0.2 \\
<2 \\
0 \\
10 \\
\end{array}$ \\
\hline $\begin{array}{l}\text { Total Time (d) } \\
\text { Interval (d) } \\
\text { pH }\left(25^{\circ} \mathrm{C}\right) \\
\text { Tot. Carbon } \\
\text { Org. Carbon } \\
\text { Inorg. Carbon } \\
\text { Formate } \\
\text { Oxalate } \\
\text { Nitrite } \\
\text { Nitrate }\end{array}$ & $\begin{array}{c}120 \\
63 \\
6.26 \\
5.3 \\
4.2 \\
1.1 \\
9.2 \\
1.4 \\
1.6 \\
7.6 \\
\end{array}$ & $\begin{array}{c}113 \\
68 \\
4.67 \\
6.1 \\
5.3 \\
0.8 \\
4.6 \\
3.8 \\
8.0 \\
2.0 \\
\end{array}$ & $\begin{array}{c}120 \\
63 \\
6.48 \\
24.9 \\
6.7 \\
18.2 \\
2.1 \\
1.8 \\
7.9 \\
2.1 \\
\end{array}$ & $\begin{array}{c}123 \\
52 \\
6.47 \\
21.9 \\
8.1 \\
13.8 \\
7.9 \\
2.4 \\
15 \\
3.2 \\
\end{array}$ & $\begin{array}{c}127 \\
53 \\
7.44 \\
21.0 \\
7.4 \\
13.6 \\
8.7 \\
2.8 \\
16 \\
2.5 \\
\end{array}$ & $\begin{array}{c}134 \\
52 \\
7.22 \\
29.9 \\
16.5 \\
13.4 \\
12 \\
<1 \\
27 \\
4.0 \\
\end{array}$ & $\begin{array}{r}134 \\
51 \\
- \\
- \\
- \\
- \\
- \\
-\end{array}$ & $\begin{array}{l}- \\
\overline{8} .36 \\
25.0 \\
5.0 \\
20.0 \\
<0.2 \\
<2 \\
0 \\
10\end{array}$ \\
\hline
\end{tabular}

aThe leachate is diluted by the EJ-13 in the base of the vessel. However, comparisons can be made to $E J-13$ concentrations.

bTest S6V1 at $134 \mathrm{~d}$ had dry test vessel when opened.

The formate ion exhibited a significant increase in parallel with a bicarbonate decrease and nitrite increase. Therefore, a possible reaction is the following:

$$
\mathrm{N} 2+2 \mathrm{H}_{2} \mathrm{O}+2 \mathrm{HCO}_{3}^{--\cdots}>2 \mathrm{NO}_{2}^{-}+2 \mathrm{HCO}_{2}^{-}+2 \mathrm{H}^{+}+\mathrm{H}_{2}
$$

The formation of formate and oxalate, as well as nitrate, during glass waste form leaching was noted previously [9]. The presence of formate and oxalate could result in the formation of highly stable actinide complexes.

\section{Actinide Analyses}

The concentrations of actinide species identified from alpha spectroscopy for unfiltered and filtered (3.6-nm filter) leachate samples are shown in Table V. No evidence of actinide transport was seen in the vapor tests; however, acid stripping of the test vessels is needed to confirm this and will be done in the future.

S32J1 had the largest amount of actinide species in the leachate. The actinide concentrations retained by the 3.6-nm filter are orders of magiitude greater than those retained by the 1.8-nm filter used in saturated tests [1]. A major fraction of the actinide material appears to be in the form of colloids (see Table V to compare unfiltered and filtered concentrations) and larger than $3.6 \mathrm{~nm}$ (see Table VIII). The americium concentration, $10^{-5} \mathrm{~g} / \mathrm{L}\left(10^{-6} \mathrm{~g} / \mathrm{L}\right.$ in filtered solutions), for these unsaturated tests is orders of magnitude greater than that reported for saturated tests, $10^{-10} \mathrm{~g} / \mathrm{L}$ [1]. This difference, if it is present at future test intervals, will indicate an enhanced source term for americium transport. 
TABLE IV. Anion Composition for Spent Fuel Leachate.

Mole change from EJ-13 content of same volume of solution.

\begin{tabular}{lllll}
\hline & \multicolumn{5}{c}{ Mole Change } \\
\cline { 2 - 5 } Test No. ${ }^{2}$ & Nitiate & Nitrite & Formaite & Bicarbonate \\
\hline CC1J1-57 & $-3.02 E-7$ & $1.58 E-7$ & $6.93 E-7$ & $-1.91 E-7$ \\
CC1J1-120 & $-8.50 E-7$ & $1.13 E-6$ & $2.82 E-7$ & $-1.99 E-7$ \\
S3V1-82 & $-5.48 E-7$ & $5.63 E-6$ & $3.51 E-6$ & $-1.69 E-6$ \\
S3V1-134 & $-9.68 E-7$ & $5.84 E-6$ & $2.62 E-6$ & $-1.08 E-6$ \\
S6V1-83b & $-3.87 E-7$ & $6.71 E-6$ & $3.51 E-6$ & $-1.59 E-6$ \\
S31J1-71 & $-2.28 E-7$ & $4.80 E-6$ & $1.89 E-6$ & $-1.56 E-6$ \\
S31J1-123 & $-6.47 E-7$ & $1.91 E-6$ & $1.01 E-6$ & $-5.99 E-7$ \\
S61J1-74 & $-3.34 E-7$ & $4.49 E-6$ & $2.34 E-6$ & $-1.56 E-6$ \\
S61J1-127 & $-7.56 E-7$ & $2.16 E-6$ & $1.18 E-6$ & $-6.52 E-7$ \\
S32J1-57 & $-6.95 E-7$ & $7.25 E-6$ & $2.06 E-6$ & $-4.77 E-6$ \\
S32J1-120 & $-7.31 E-7$ & $6.07 E-7$ & $3.78 E-6$ & $-5.85 E-6$ \\
S62J1-55 & $-1.20 E-6$ & $6.13 E-6$ & $2.02 E-6$ & $-4.25 E-6$ \\
S62J1-113 & $-2.19 E-6$ & $2.91 E-6$ & $1.66 E-6$ & $-5.35 E-6$ \\
\hline
\end{tabular}

aNumber after hyphen gives test time in days.

bTest vessel was dry due to a leak.

TABLE V. Actinide Speciesa Detected by Alpha Spectroscopy for Successive Unfiltered and Filtered Leachate Samples

\begin{tabular}{|c|c|c|c|c|c|}
\hline \multirow[b]{2}{*}{ Test No.b } & \multicolumn{5}{|c|}{ Content from Unfiltered Sample, $\mathrm{g} / \mathrm{L}$} \\
\hline & $\mathrm{Cm}-244$ & Am-241 & Pu-239 & $\mathrm{Np}-237$ & Am-243 \\
\hline $\begin{array}{l}C C 1 J 1-57 \\
\text { CC1J1-120 } \\
\text { S31J1-71 } \\
\text { S31J1-123 } \\
\text { S61J1-74 } \\
\text { S61J1-127 } \\
\text { S32J1-57 } \\
\text { S32J1-120 } \\
\text { S62J1-113 }\end{array}$ & $\begin{array}{c}3.9 \mathrm{E}-11 \\
3.2 \mathrm{E}-11 \\
2.1 \mathrm{E}-7 \\
4.0 \mathrm{E}-9 \\
3.8 \mathrm{E}-10 \\
3.0 \mathrm{E}-9 \\
4.9 \mathrm{E}-6 \\
2.0 \mathrm{E}-6 \\
4.1 \mathrm{E}-8\end{array}$ & $\begin{array}{c}6.8 \overline{\mathrm{E}}-10 \\
1.3 \mathrm{E}-6 \\
3.8 \mathrm{E}-7 \\
7.0 \mathrm{E}-10 \\
1.9 \mathrm{E}-8 \\
3.6 \mathrm{E}-5 \\
1.3 \mathrm{E}-5 \\
2.1 \mathrm{E}-7\end{array}$ & $\begin{array}{c}3 . \ddot{4 E-8} \\
-\ddot{2 E-6} \\
-- \\
-- \\
-- \\
-- \\
--\end{array}$ & $\begin{array}{c}6 . \overline{6}-6 \\
-- \\
-- \\
-- \\
-- \\
-- \\
- \\
- \\
\end{array}$ & $\begin{array}{c}- \\
- \\
- \\
-- \\
-- \\
-. \\
8.5 \mathrm{E}-6 \\
-- \\
3.4 \mathrm{E}-7\end{array}$ \\
\hline Test No.b & \multicolumn{5}{|c|}{ Content of Filtered Sample, $\mathrm{g} / \mathrm{L}$} \\
\hline $\begin{array}{l}\text { S31J1-71 } \\
\text { S31J1-123 } \\
\text { S61J1-74 } \\
\text { S61J1-127 } \\
\text { S } 32 J 1-57 \\
\text { S } 32 J 1-120 \\
\text { S62J1-113 }\end{array}$ & $\begin{array}{c}1.9 \mathrm{E}-8 \\
1.5 \mathrm{E}-9 \\
2.7 \mathrm{E}-10 \\
3.1 \mathrm{E}-10 \\
1.7 \mathrm{E}-7 \\
2.1 \mathrm{E}-7 \\
4.7 \mathrm{E}-9 \\
\end{array}$ & $\begin{array}{l}1.8 \mathrm{E}-7 \\
1.8 \mathrm{E}-8 \\
3.8 \mathrm{E}-10 \\
7.8 \mathrm{E}-9 \\
1.2 \mathrm{E}-6 \\
9.1 \mathrm{E}-7 \\
4.5 \mathrm{E}-9\end{array}$ & $\begin{array}{c}-- \\
-- \\
-- \\
4.5 \mathrm{E}-7 \\
2.9 \mathrm{E}-7 \\
--\end{array}$ & $\begin{array}{c}-- \\
-- \\
-- \\
1 . \overline{1 E-4} \\
2.2 E-5 \\
--\end{array}$ & $\begin{array}{c}- \\
- \\
-- \\
-\overline{-} \\
6.4 \mathrm{E}-8 \\
4.8 \mathrm{E}-8 \\
.-\end{array}$ \\
\hline \multicolumn{6}{|c|}{$\begin{array}{l}\text { aThese are minimums since actinides on holders and vessel surfaces have } \\
\text { not been determined. Although Pu-238 and Am-241 have alpha particles of the } \\
\text { same energy, the alpha assignment was made to Am-241 since the correct } \\
\text { Pu-238/Pu-239 ratio was not found and Am-243 was detected. Preliminary } \\
\text { ICP-MS results indicate little plutonium in the ATM-103 leachate but comparable } \\
\text { amounts of Am and Pu in the ATM-106 leachate. } \\
\text { bNumber following hyphen is time in days. }\end{array}$} \\
\hline
\end{tabular}


Actinide release with ATM-106 fuel differed from that with ATM-103 fuel. For the ATM-106 fuel (S61J1 and S62J1), actinide release was not detected during the first two months of testing and the amount was two orders of magnitude less than that found for ATM-103 fuel (S32J1 and S31J1) In addition, S61J1 and S31J1 have an actinide release rate an order of magnitude less than that in the higher injection rate tests (S62J1 and S32J1). At 113-120 days, the amounts of actinide detected for the latter tests are only one order of magnitude apart because the release rate for ATM-103 decreased in the second time interval. The ATM-106 samples were originally expected to exhibit a larger release of "gap and grain" boundary elements than ATM-103 samples; this was not the case. However, an increased release rate may occur for ATM-106 tests at longer times.

The species detected from gamma spectroscopy are shown in Table VI. Cesium was detected in all tests for the first interval except in S6V1. Europium was detected from both injection tests with ATM-103 fuel (S32J1 and S31J1) and from the ATM-106 test with the higher injection rate (S62J1). In addition, americium was detected in both injection tests with ATM-103. In the second interval, cesium was detected in all tests. Americium was detected in the high injection test with ATM-106 fuel as well as both injection tests with ATM-103 fuel.

In Table VII, the amounts of americium determined from alpha and gamma spectroscopy are compared. There is an order of magnitude or more difference, with the alpha results being lower which may be the result of attenuation of the alpha samples produced by solution evaporation on planchets. The discrepancy is included since the gamma results indicate even higher actinide transport for the unsaturated tests.

\section{Transmission Electron Microscopy}

Table VIII summarizes the TEM results obtained by wicking a drop of solution through a holey carbon grid. Comparable species were found for samples from S32J1-57 and S61J1-127, tests with different fuels and different injection rates. For both, the primary phases were calcium silicate and hydrated schoepite, a uranium oxide phase. Rare earth elements were also detected in the two samples.

TABLE VI. Species (in grams) Detected by Gam'ma Spectroscopy for Leachate Samples for Two Intervals

\begin{tabular}{lcccccc}
\hline Sample & S3V1 & S31J1 & S32J1 & S61J1 & S62J1 & CC1J1a \\
\hline Day & 82 & 71 & \multicolumn{1}{c}{57} & 74 & 55 & 57 \\
\hline Cs-137 & $3.4 \mathrm{E}-12$ & $8.0 \mathrm{E}-8$ & $2.7 \mathrm{E}-6$ & $5.6 \mathrm{E}-11$ & $2.3 \mathrm{E}-10$ & $1.3 \mathrm{E}-11$ \\
Cs-134 & -- & $1.7 \mathrm{E}-10$ & $5.6 \mathrm{E}-9$ & $1.1 \mathrm{E}-13$ & $5.6 \mathrm{E}-13$ & $2.0 \mathrm{E}-14$ \\
Eu-154 & -- & $6.3 \mathrm{E}-11$ & $8.2 \mathrm{E}-8$ & -- & $5.2 \mathrm{E}-13$ & - \\
Eu-155 & -- & $5.9 \mathrm{E}-12$ & $1.4 \mathrm{E}-8$ & - & -- & - \\
Am-243 & -- & $1.9 \mathrm{E}-8$ & $1.5 \mathrm{E}-6$ & - & -- & - \\
Am-241 & -- & - & $3.0 \mathrm{E}-6$ & - &.- & - \\
Np-237 & -- & $2.6 \mathrm{E}-5$ & -- & -- &.- & - \\
\hline \hline Day & 134 & 123 & 120 & 127 & 113 & 120 \\
\hline Cs-137 & $7.0 \mathrm{E}-13$ & $6.0 \mathrm{E}-9$ & $4.1 \mathrm{E}-6$ & $4.1 \mathrm{E}-10$ & $9.0 \mathrm{E}-9$ & $3.1 \mathrm{E}-12$ \\
Cs-134 & -- & $1.1 \mathrm{E}-11$ & $7.7 \mathrm{E}-9$ & $9.5 \mathrm{E}-13$ & $9.8 \mathrm{E}-10$ & -- \\
Eu-154 & -- & $3.7 \mathrm{E}-12$ & $2.8 \mathrm{E}-9$ & -- & $1.2 \mathrm{E}-11$ & -- \\
Am-243 & -- & $1.2 \mathrm{E}-10$ & $6.0 \mathrm{E}-6$ & -- & $1.0 \mathrm{E}-7$ & -- \\
\hline
\end{tabular}

aNo fuel was present, so the results indicate possible contamination. 
TABLE VII. Comparison of Gamma (G) and Alpha (A) Results for Americium

\begin{tabular}{|c|c|c|c|c|}
\hline \multirow[b]{3}{*}{ Test No.a } & \multicolumn{4}{|c|}{ Amount Detected, $g / L$} \\
\hline & \multicolumn{2}{|c|}{ Am-241 } & \multicolumn{2}{|c|}{ Am-243 } \\
\hline & $\mathbf{G}$ & $\bar{A}$ & $\mathbf{G}$ & A \\
\hline $\begin{array}{l}\text { S32J } 1-57 \\
\text { S32J 1-120 }\end{array}$ & $\begin{array}{c}2.7 E-4 \\
-.\end{array}$ & $\begin{array}{l}3.6 \mathrm{E}-5 \\
1.3 \mathrm{E}-5\end{array}$ & $\begin{array}{l}1.4 E-4 \\
5.0 E-4\end{array}$ & $\begin{array}{l}8.5 E-6 \\
4.8 E-8 b\end{array}$ \\
\hline S62J1-113 & -. & 2.1E-7 & $9.4 E-6$ & $3.4 \mathrm{E}-7$ \\
\hline
\end{tabular}

aNumber following hyphen is time in days.

bResults are for unfiltered samples, except for this sample.

TABLE VIII. Transmission Electron Microscope Results for Leachate Solutions

\begin{tabular}{|c|c|c|c|}
\hline Samplea & Phases & Comments & Elements \\
\hline $\begin{array}{l}\text { S62J1-55NF } \\
\text { S62J1-55F } \\
\text { S32J1-57NF }\end{array}$ & $\begin{array}{l}\text { Aluminum particles } \\
\text { Aluminum silicate } \\
\text { Schoepite hydrate } \\
\text { Calcium silicate }\end{array}$ & $\begin{array}{l}\text { Agglomerated } \\
\text { Individ. } 50-100 \mathrm{~nm} \\
\text { Agglomer. }>4000 \mathrm{~nm}\end{array}$ & $\begin{array}{l}\mathrm{Pb}, \mathrm{Fe}, \mathrm{Ni} \\
\mathrm{U}, \mathrm{Ca}, \mathrm{Pb}, \mathrm{Cr} \\
\text { REEC }\end{array}$ \\
\hline S32J1-57F & Silica & -- & -- \\
\hline S61J & Dolomite, silica & -- & -- \\
\hline S6V1-83 & Steel particle & -- & -- \\
\hline S62J1-113 & Calcium phases & Particles, agglom. & $\mathrm{Ca}, \mathrm{Zn}$ \\
\hline S32J1-120 & & & \\
\hline S31J1-123 & $\begin{array}{l}\text { Calcium phase, } \\
\text { calcite }\end{array}$ & -- & $\mathrm{Ca}, \mathrm{Zn}$ \\
\hline S61J1-127 & $\begin{array}{l}\text { Caicium silicate } \\
\text { Schoepite hydrate }\end{array}$ & $\begin{array}{l}\text { Opaque particles } \\
50-4000 \mathrm{~nm}\end{array}$ & $\begin{array}{l}\text { U, } \mathrm{Zn}, \mathrm{Pb}, \mathrm{Fe}, \mathrm{Ti} \text {, } \\
\text { REEC }\end{array}$ \\
\hline \multicolumn{4}{|c|}{$\begin{array}{l}\text { aNumber following hyphen indicates time in days. Also, NF = not prefiltered, } \\
F=\text { prefiltered with } 3.6-n m \text { filter. } \\
\text { bA summary of findings from two samples, the secend prepared several months } \\
\text { later. } \\
\text { CREE = rare earth elements. }\end{array}$} \\
\hline
\end{tabular}

The best TEM sample, that from S32J1-57, contained two major intermixed uranium phases. The first phase, identified as schoepite, was composed of large (3-5 $\mu \mathrm{m}$ diam.) flocculent-like particles which were built from individual particles 40-50 $\mathrm{nm}$ in diameter. The rare earths detected by electron energy loss spectroscopy were $\mathrm{La}, \mathrm{Ce}, \mathrm{Pr}, \mathrm{Nd}$, and $\mathrm{Sm}$, with some evidence for $\mathrm{Eu}$ and $\mathrm{Ba}$. The second phase consisted of uranium-bearing agglomerated particles with a platelet-like morphology. In addition, large agglomerates of silica and calcium silicate particles were observed, as well as steel and alumina particles. The agglomeration may be the result of sample preparation on the grids.

\section{CONCLUSIONS}

From these results, we suspect that actinide transport from the waste form will be significantly affected by the leachate $\mathrm{pH}$. Under unsaturated conditions, radiolysis products are not diluted; therefore, they decrease the leachate $\mathrm{pH}$ which 
results in higher actinide solubilities. In saturated tests, the $\mathrm{pH}$ effect is masked by the large volume of liquid. In addition, a large fraction of the actinides (ten times the soluble fraction for americium and curium) are bound in colloids, as evidenced by the unfiltered and filtered results from alpha spectroscopy. The presence of excess organic species may be the agents enhancing this form of transport. If the behavior of these species is verified in future test intervals, their importance would have to be addressed in transport models for the proposed repository system.

\section{ACKNOWLEDGMENTS}

This task is performed under the guidance of the Yucca Mountain Site Characterization Prolect (YMP) and is part of activity D-20-43 as indicated in the YMP/LLNL Spent Fuel Scientific Investigation Plan. The work was funded by internal ANL research and development funding. Del Bowers, ACLANL, is thanked for the anion analysis. Work supported by the U.S. Department of Energy under contract W-31-109-ENG-38.

\section{REFERENCES}

1. C. N. Wilson, Results from NNWSI Series 3 Spent Fuel Dissolution Tests, Pacific Northwest Laboratory Report PNL-7170 (1990), and references therein.

2. S. N. Nguyen, H. C. Weed, H. R. Leider, and R. B. Stout, Dissolution Kinetics

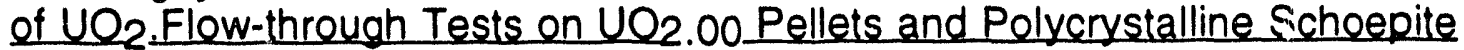
Samoles in Oxygenated. Carbonate/Bicarbonate Buffer Solutions at $25^{\circ} \mathrm{C}$, Lawrence Livermore National Laboratory Report, UCRL-JC-107478 (1991).

3. C. N. Wilson and W. J. Gray, "The Effects of Water Composition on the Dissolution Rate of $\mathrm{UO}_{2}$ Under Oxidizing Conditions," 1st Annual Internat. High-Level Radioactive Waste Mgmt. Conf., Las Vegas, April 1990.

4. J. K. Bates and T. J. Gerding, One-Year Results of the NNWSI Unsaturated Test Procedure: SRL 165 Glass Application, Argonne National Laboratory Report ANL-85-41 (1986).

5. W. E. Glassley, Reference Waste Package Environment Report, Lawrence Livermore National Laboratory Report UCRL-53726 (1986).

6. R. J. Guenther et al., Characterization of Spent Fuel Approved Testing Material - ATM-103, Pacific Northwest Laboratory Report PNL-5109-103 (1988).

7. R. J. Guenther et al., Characterization of Spent Fuel Approved Testing Material - ATM-106, Pacific Northwest Laboratory Report PNL-5109-106 (1988).

8. J. F. Kerrisk and R. J. Silva, "A Consistent Set of Thermodynamic Constants for Americium(III) Species with Hydroxyl and Carbonate," Proc. Workshop on Geochemical Modeling, CONF-8609134, pp. 167-175 (1986).

9. Aa. Barkatt, Al. Barkatt, and W. Sousanpour, "Gamma Radiolysis of Aqueous Media and Its Effects on the Leaching Processes of Nuclear Waste Disposal Materials," Nucl. Technol. 60, 218-227 (1983). 

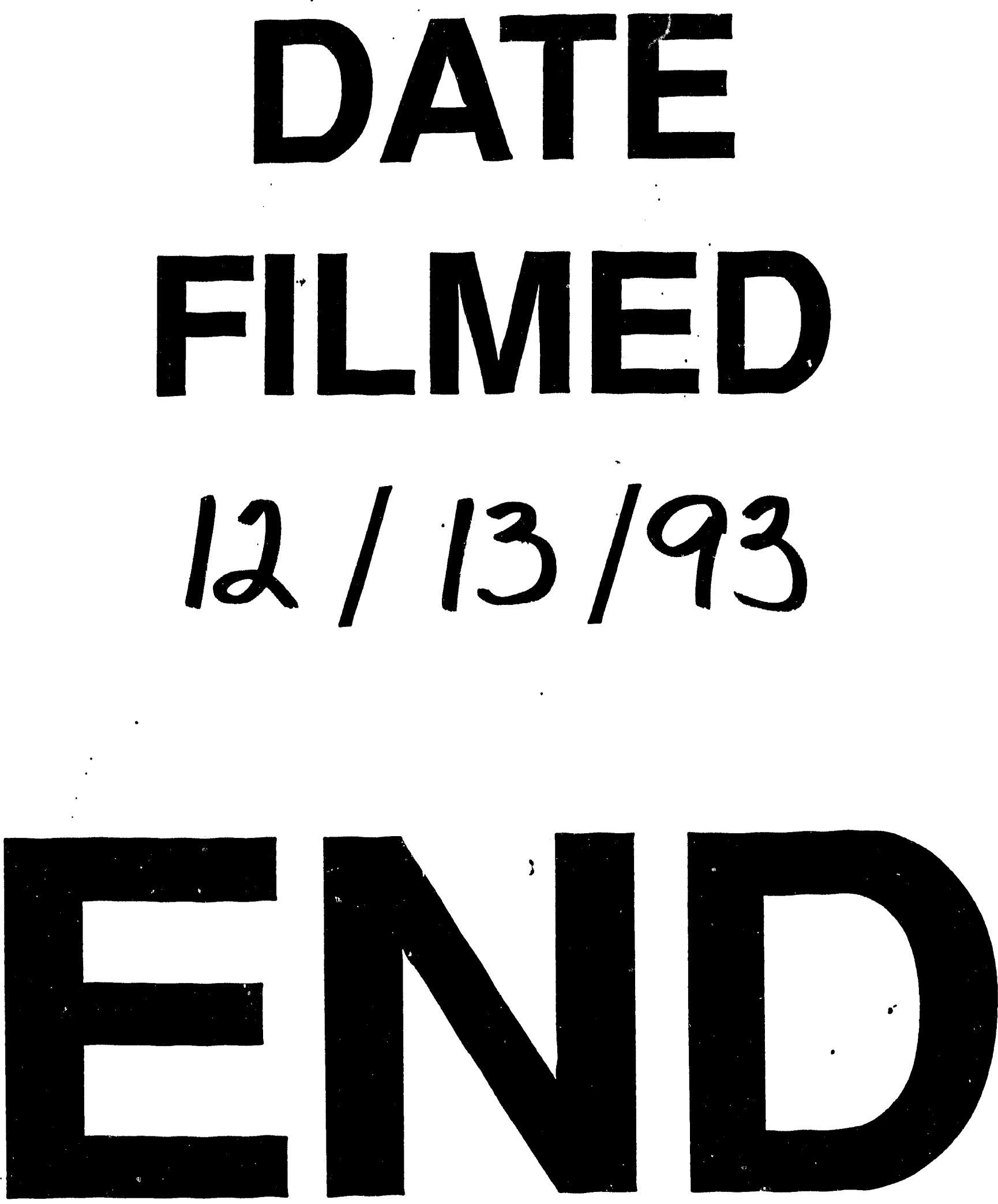
